\title{
ARTICLE
}

\section{Rapa Nui (Easter Island)'s Stone Worlds}

\author{
Sue Hamilton*
}

This article explores the spatial, architectural and conceptual relationships between landscape places, stone quarrying, and stone moving and building during Rapa Nui's statue-building period. These are central themes of the 'Rapa Nui Landscapes of Construction Project' and are discussed using aspects of the findings of our recent fieldwork. The different scales of expression, from the detail of the domestic sphere to the monumental working of quarries, are considered. It is suggested that the impressiveness of Rapa Nui's stone architecture is its conceptual coherence at the small scale as much as at the large scale.

The remarkable nature of Rapa Nui (Easter Island) is so much more than its renowned colossal statues, known as moai. The moai are indisputably monumental; those set up on stone ceremonial platforms $(a h u)$ are up to $10 \mathrm{~m}$ in height (Fig. 1), while even larger statues, up to a vast $22 \mathrm{~m}$, remain at the statue quarry of Rano Raraku. However, what is most impressive and intellectually stimulating is the island-wide scale and interconnectivity of the architectural outcomes and meaning endowed in its prehistoric stone garnering, quarrying and construction activities (Hamilton et al., 2011). The 'Rapa Nui Landscapes of Construction Project' (LOC) is particularly concerned with the social and conceptual meanings of these construction undertakings and stone use. The Project was first reported in Archaeology International, when it was initially supported by a small grant from the British Academy (Hamilton, 2007). We are now two field seasons into a 4-year programme of AHRC-funded research. This AHRC project is based at UCL, in con-

\footnotetext{
* UCL Institute of Archaeology, London WC1H OPY, United Kingdom s.hamilton@ucl.ac.uk
}

junction with co-investigators Colin Richards (University of Manchester) and Kate Welham (Bournemouth University), and our Project Partner, the University of the Highlands and Islands (led by Jane Downes). On the Island, the Project works with Rapa Nui elders and students and in close cooperation with CONAF (Chilean National Parks Authority, Rapa Nui) and MAPSE (the Island's Museo Antropologico Padre Sebastian Englert).

\section{Living archaeology}

No archaeological fieldwork can or should be independent of the particular locale in which it takes place. Rapa Nui has a uniquely marooned island location, a difficult history and, today, a dynamic living community of c.5,000 persons. These three elements are at the core of any archaeological undertakings on the Island.

Rapa Nui is a small South Pacific island of 164 square kilometres (Fig. 2) at the southeasternmost point of the Polynesian Triangle made between Hawai'i, Aukland Island and Rapa Nui. It is surrounded by an infinity of sea, lying some $2,000 \mathrm{~km}$ from its nearest neighbour, Pitcairn Island, and 3,700km from the mainland, Central Chile. Language 


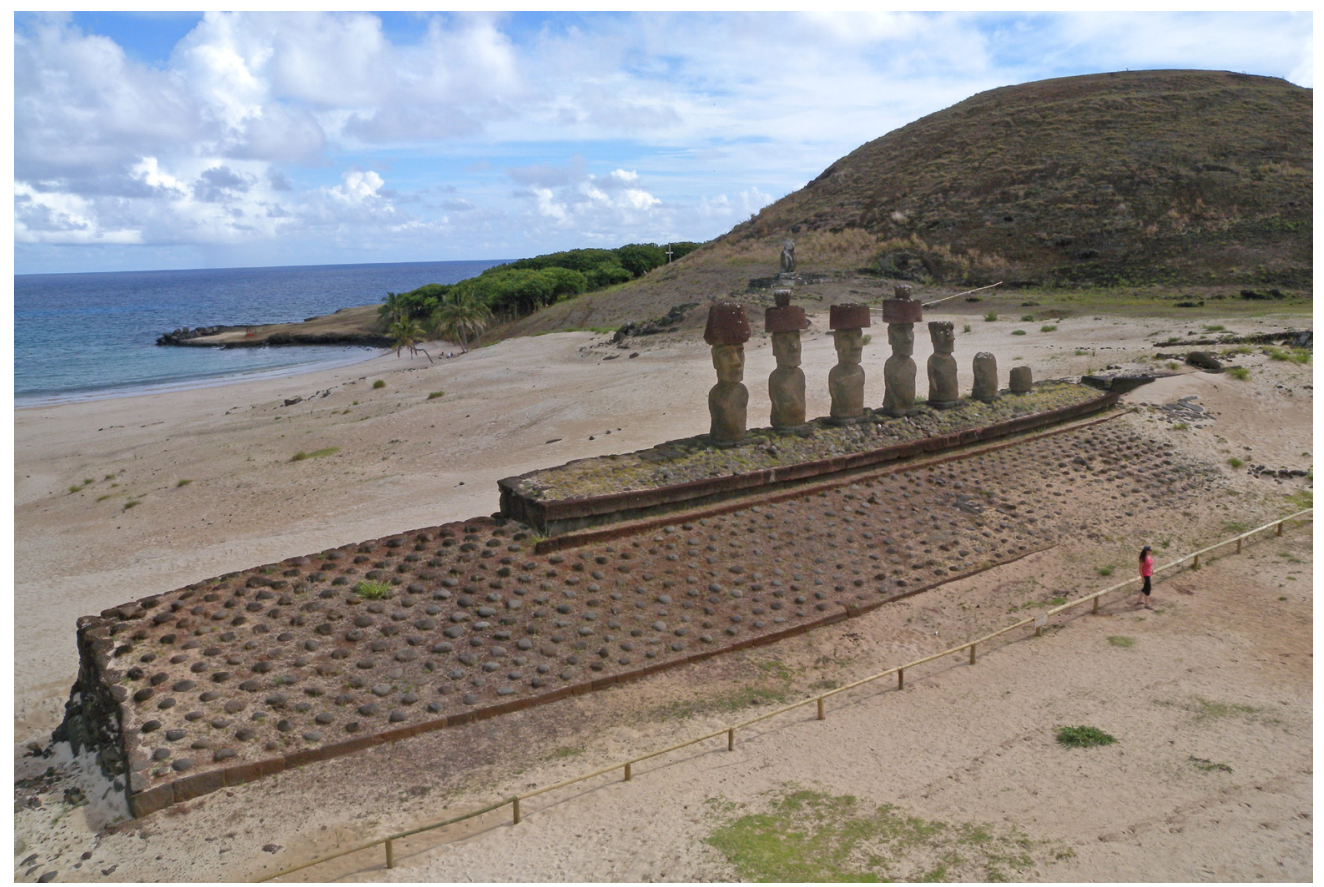

Fig. 1: Ahu Nau Nau, showing the canoe-shaped ahu platform, its poro (sea boulder) ramp and partly poro-paved plaza on the landward side, and Rano Raraku statues with pukao ('hats') in place.

characteristics, material culture and genetic analysis of mitochondrial DNA of prehistoric skeletons (Hagelberg, 1995) all indicate that Rapa Nui was first colonised by eastward voyaging Polynesians. The debated origin point includes an island in the Marquesas group, and Mangareva amongst the possibilities (Flenley and Bahn, 2003: chapter 2). The arrival date of the founder population has been much disputed. Traditionally, on the basis of glottochronology, dated stratified finds and palaeo-environmental sequences, a 'start' date as early as c.AD 800 has been advanced. More recent radiocarbon dates, and a critique of the pre-existing sequences and dates, suggest a later date of around the 11th century AD for the arrival of Polynesian colonists (Flenley and Bahn, 2007a; 2007b; Hunt and Lipo, 2006; Wilmhurst et al., 2010). Either way, the construction of Rapa Nui's iconic monuments appears to have been fully established by AD 1200.
The Island's extreme isolation, the suggested fragility of its fossil volcanic landscape and its low biodiversity, Polynesian-introduced rats and, following its discovery by Europeans in 1772, the imported diseases/ epidemics that the outside world brought to the Island in the mid-late 19th century, have all variously been used to account for Rapa Nui's cultural heights and troughs (Diamond, 2005; Hunt and Lipo, 2007; Sahlins, 1955). These include Rapa Nui's remarkable cultural efflorescence during the statuebuilding period, the cessation of statue quarrying c.AD 1650, with associated profound changes in the political system, and the disastrous plummet in population size, down from estimates of up to c.6,000 persons by the first European visitors to the 111 inhabitants recorded in the 1872 census (Flenley and Bahn, 2003: 169).

Today, Rapa Nui is part of Chile, having been annexed in 1888. From 1903 until 1953 the island was rented for intensive sheep 


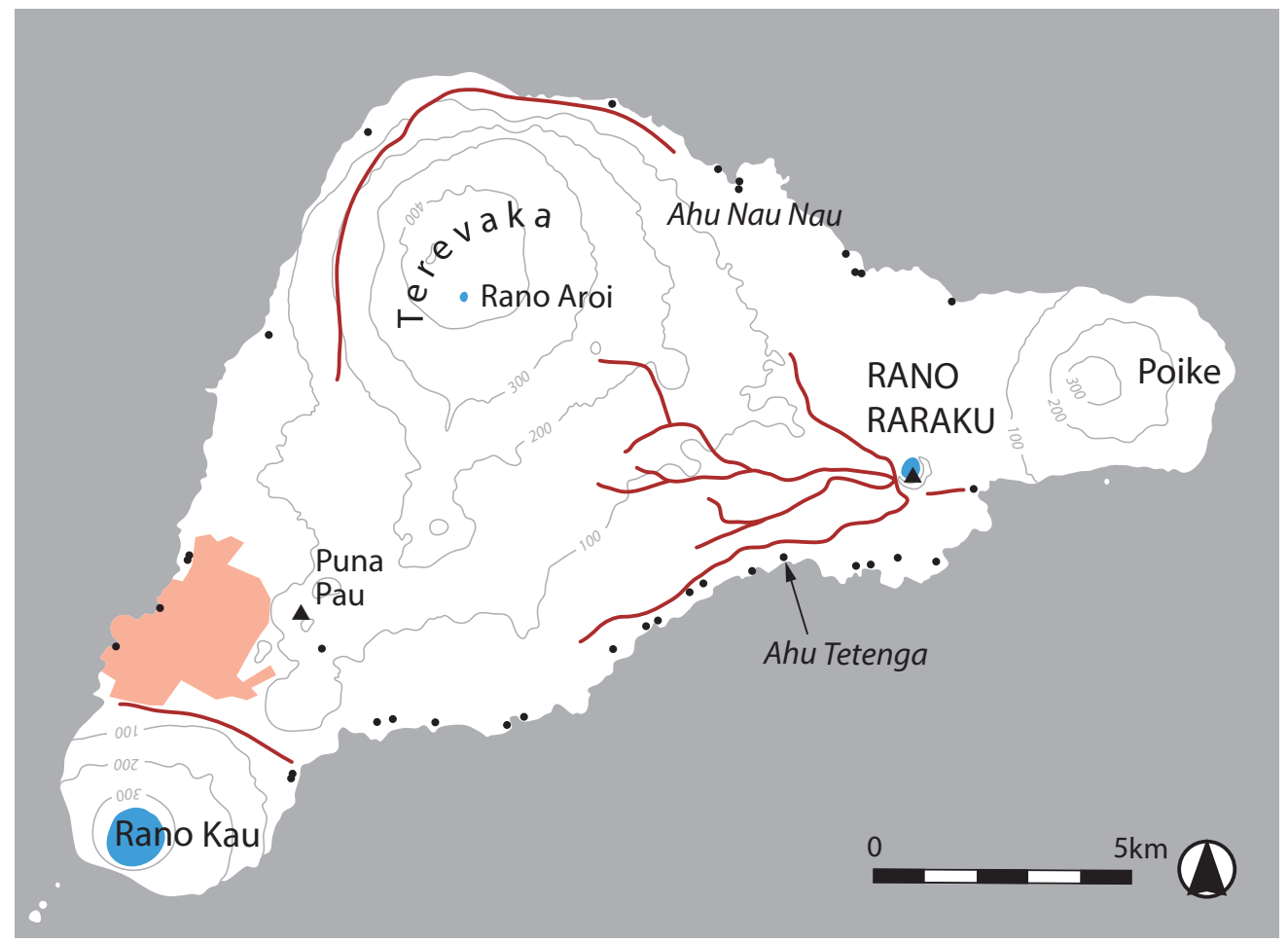

Fig. 2: Map of Rapa Nui, showing the places mentioned in the text, including the statue roads; the area of red shading is the present-day town of Hanga Roa. The locations of some of the major image $a h u$ (ahu with statues) around the coast are marked by black dots; $>100$ of the $a h u$ around the coast may originally have had statues, but these are too numerous to depict here (Martinsson-Wallin, 1994).

rearing. This resulted in the Rapa Nui population being forced off the land and being contained within the Island's only settlement of Hanga Roa (Fig. 2). Paradoxically, this also resulted in the preservation of the Island's remarkably continuous landscapes of stone archaeological features that are the mainstay of its tourist economy today. This landscape includes: ahu (Fig. 1); houses (including canoe-shaped houses: hare paenga); earthern cooking ovens with stone surrounds (umu); rock gardens and walled enclosures for plantings (manavai); chicken houses (hare moai); quarries and statue roads; and a substantial repertoire of petroglyphs. The great importance of this archaeological landscape was recognised by Chile in declaring Rapa Nui as a National Park in 1935. Since 1996 Rapa Nui has been designated a UNESCO Cultural
Landscape. The first commercial air-flights to Rapa Nui began in the 1960s and have greatly increased in recent times. Approximately 70,000 tourists now visit Rapa Nui each year. Concurrently, there has been a major revival of interest in indigenous traditions and in fostering and maintaining Rapa Nui identity and independence. The Chilean government is now returning land to the Rapa Nui - and there is an urgent need to understand how the integrity of the archaeology across the Rapa Nui landscape can best be maintained as part of this important process.

Rapa Nui thus has a living archaeology that is meaningful and integral to the present-day Rapa Nui community, their sense of identity and their understanding and use of the Island. LOC aims to work with the Rapa Nui community to provide training and help to record, 

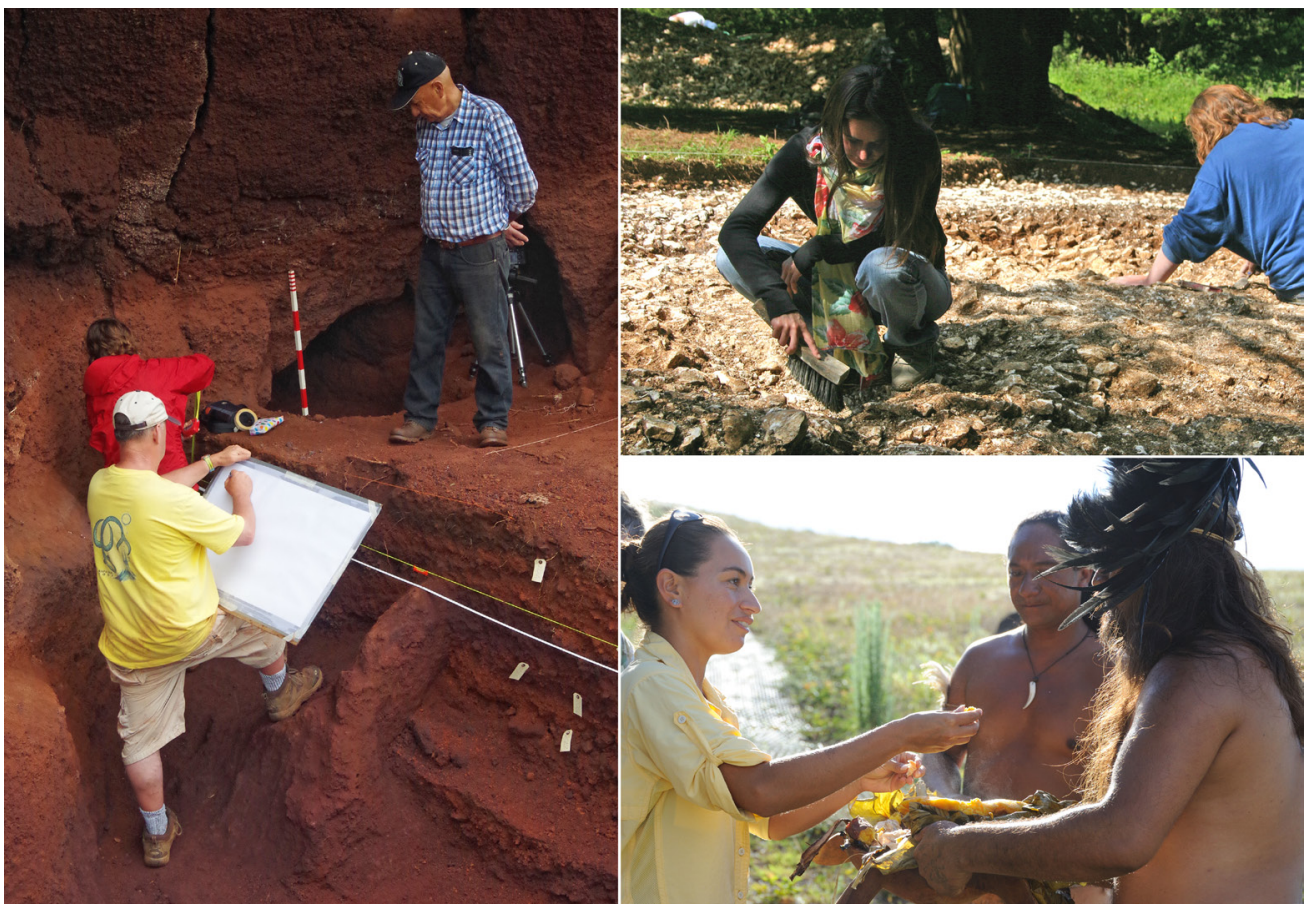

Fig. 3: Rapa Nui colleagues. Clockwise from left: Sorobael Fati overlooking the 2013 excavations in the interior of Puna Pau (Colin Richards and Jane Downes are planning the deeply stratified quarry tip lines); Francisca Pakomio on the UCL Institute of Archaeology training excavation at West Dean, West Sussex; and Susana Nahoe, Archaeologist for CONAF Rapa Nui participating in our umu ceremony at the end of a Puna Pau excavation season (photos: M. Seager Thomas).

investigate and conserve their own remarkable archaeological past. In doing so LOC hopes to build a framework of knowledge that concurrently elucidates research questions and works collaboratively with the Rapa Nui community and authorities to provide resources and information for presenting Rapa Nui's pre-contact past. Several Rapa Nui students, supervised by Sorobael Fati, a Rapa Nui elder (Fig. 3), have worked regularly with us on our excavations, and last summer the Project set up a Bursary with UCL to bring a Rapa Nui university student studying archaeology to the UK, to join the Institute of Archaeology's field training course at West Dean, West Sussex. Francisca Pakomio was the first recipient of this award (Fig. 3).

In a similar ethos we are working with CONAF to assist monitoring and managing
Rapa Nui's archaeological landscape. In January/February 2013, we undertook a survey for CONAF of the south-west branch of the 'statue road' (Ara Moai), from Rano Raraku to Ahu Tetenga (Fig. 2): to verify and assess the archaeological context of its route; to study the state of preservation of the so-called in transport statues' along the route; and to make suggestions as to how best develop a tourist 'Ara Moai' trekking trail while protecting the archaeology of the route. This work has allowed us to consider the role and function of the 'statue roads' as connectors of the communities associated with the ahu at the coastline with Rano Raraku quarry.

Some of LOC's recent fieldwork work, its interpretative framework and how it is being developed to provide an integrated, island-wide understanding of the sites and 
monuments of the statue-building period, is discussed below.

\section{Landscape boundaries with other worlds}

Rapa Nui is triangular in shape and consists mainly of three extinct coalesced volcanoes: Terevaka, at an altitude of $507 \mathrm{~m}$, forms the bulk of the island, with two other volcanoes, Poike and Rano Kau, forming the eastern and southern tips (Fig. 2). Lesser cones and other volcanic features include the crater Rano Raraku, where the majority of the statues were carved, and the cinder cone of Puna Pau, where the red scoria statue 'topknots' or 'hats' (pukao) were quarried and also facing stones for the $a h u$ platforms. There are three rano (freshwater crater lakes), at Rano Kau, Rano Raraku and Rano Aroi, near the summit of Terevaka, and a spring (puna) near Puna Pau. There are no permanent streams or rivers so that these sources of freshwater are exceptional in an otherwise waterless landscape; hence they have distinct phenomenological, as well as practical, qualities. There are also numerous volcanic caves, many below ground, that were used by the inhabitants for a range of activities and uses, including burial.

The founder population may have transferred the conceptual importance of certain landscape places in Polynesian societies to Rapa Nui. In Polynesian cosmologies recurrent themes are: the importance of volcanoes and their crater vents as conduits between above-ground and interior worlds; concerns with boundaries between 'outer' and 'inner' worlds; and the idea that the spirits of the dead travelled homeward across the sea, westward to a point of ancestral origin (Williamson, 1933). We discuss these concerns in a Rapa Nui context below.

\section{The Puna Pau red 'topknots'}

The Project's focus of excavation has been in the Puna Pau quarry (Figs 3 and 4), which is situated in the south-west of the Island. More than 100 pukao ('topknots' or 'hats') of red scoria are known either from the Puna
Pau quarry and its outer slopes or from $a h u$. They are all made of the coarse, porous, dark red lava that comes from Puna Pau and are monumental in their own right, being large squat cylinders up to $2.5 \mathrm{~m}$ tall and likewise in diameter. Ours are the first ever excavations at Puna Pau and are important for dating and defining activity at the quarry. The obsidian hydration dates that we obtained from our excavations on the outside of the crater indicate quarrying activity there from the 14th-17th centuries AD. This is in line with the established and later periods of statue use at the $a h u$. Quarrying inside the crater may have started earlier, and we await obsidian hydration dates and radiocarbon dates for LOC's recent (2012/13) excavations in Puna Pau's interior.

We have used laser scanning and Global Position Satellite survey to map the complex present-day topography of Puna Pau (Fig. 4). This complexity is the outcome of the reconfiguration of the exterior and interior of the cone by the major prehistoric quarrying activities that took place. Clearly, evidence of the earliest quarrying activities lies very deep below the present-day surface. We have used tomography (Fig. 4), a form of geophysical prospecting that provides sections through deeply accumulated strata, together with electro-conductivity and fluxgate magnetometry survey, to investigate the existence of both short-lived and more formalised routes through and out of the quarry for the roughed-out pukao.

LOC's first excavation trench was located on the quarry exterior where a line of quarried pukao runs down the side of the cone. This was where our tomography survey had previously isolated the possibility of a compact 'road' surface adjacent to the line of pukao (Hamilton, 2007: fig. 6). Excavation in the vicinity of one of these pukao did uncover an ancient road surface, with evidence that the pukao had been deliberately placed to the side of it, in a ramped hollow (Fig. 4). A finely-flaked obsidian adze had been placed, perhaps symbolically, underneath the base of this pukao. This suggests 


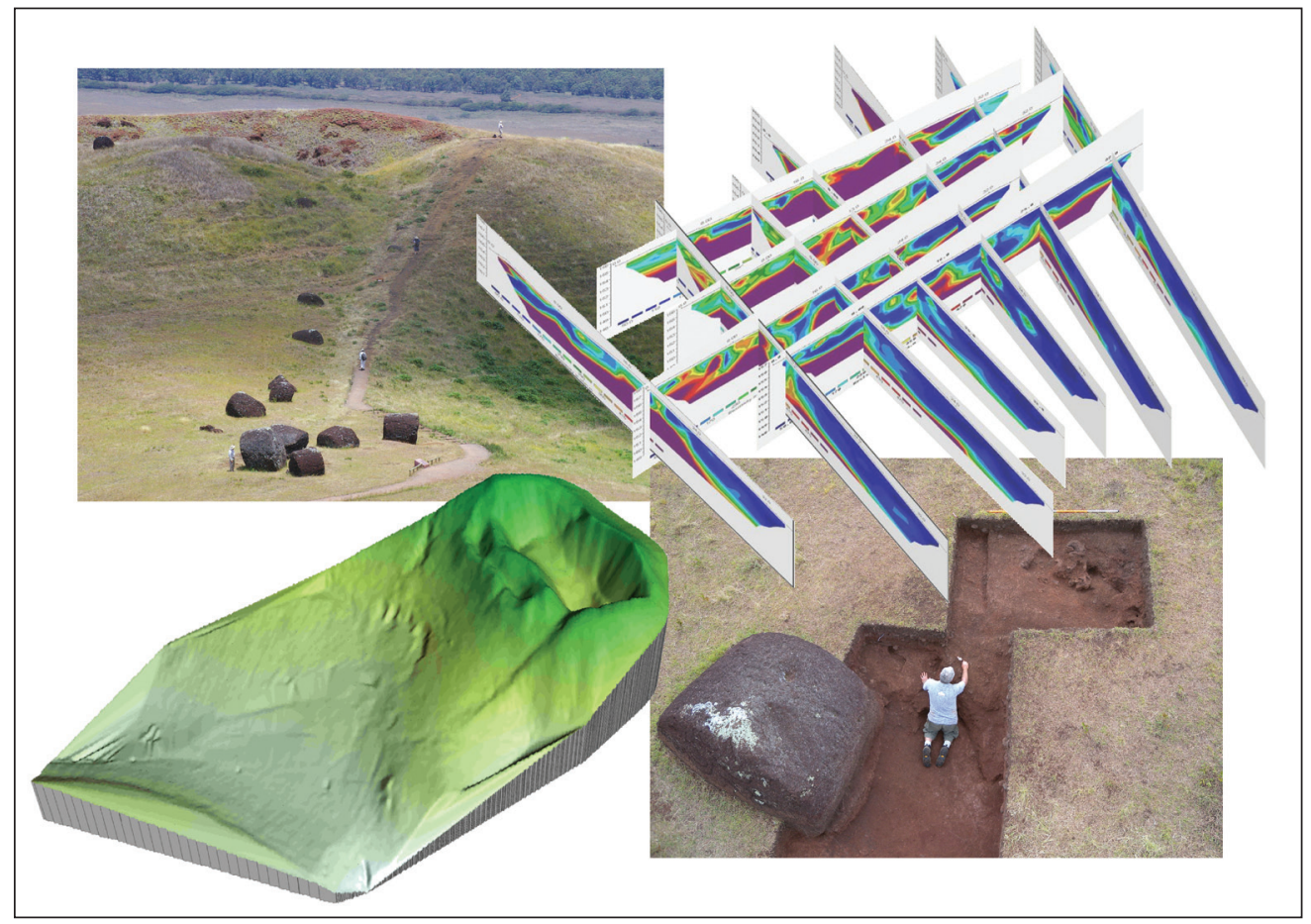

Fig. 4: Fieldwork at Puna Pau. Clockwise from top left: exterior of the Puna Pau crater, with the line of pukao marking the main route out of the quarry (photo: M. Seager Thomas); tomography analysis of the exterior of Puna Pau (image: S. Ovenden); excavation of a pukao and associated 'road surface' on the exterior of Puna Pau (photo: A. Stanford); and laser scanned topography of Puna Pau (image: K. Welham).

that the pukao running down the exterior of the Puna Pau cone were formally positioned as a monumental row marking a $\mathrm{road} /$ formal route-way into the quarry interior. The implication of this is that the quarry crater was meaningful in its own right - and that this was signalled by monumentally enhancing entry into it.

Today, within Puna Pau's interior, there are few remaining visible outcrops of workable scoria, the most pronounced of which form part of the southern slope, where a 'rockface' revealing different bands of red scoria is visible. It appeared that some bands or strata had been exploited for pukao production and so this location was selected for one of the 2012/13 excavation trenches. This revealed the remains of bays from which the pukao were quarried and a carved pair of large 'eyes' above an emptied quarry bay (Fig. 5).
The eyes have a diameter of c.0.18m, with slightly protruding eyeballs, and are $0.3 \mathrm{~m}$ apart. They are of a size that means they can be seen from the lip of the crater prior to entering the quarry. These eyes add further to the idea that symbolism/sacred meaning was attached to the cinder cone and its associated quarrying activities.

Excavation of a second trench in the quarry interior, proximate to one of a group of pukao rough-outs lying on the present-day quarry surface, located a multi-surfaced road through the quarry that had already been picked up by our resistivity survey. Excavations there, and associated with the quarry face, have produced the first stratified assemblages of quarrying and working tools associated with pukao production. These tools comprise stone types from many locales 


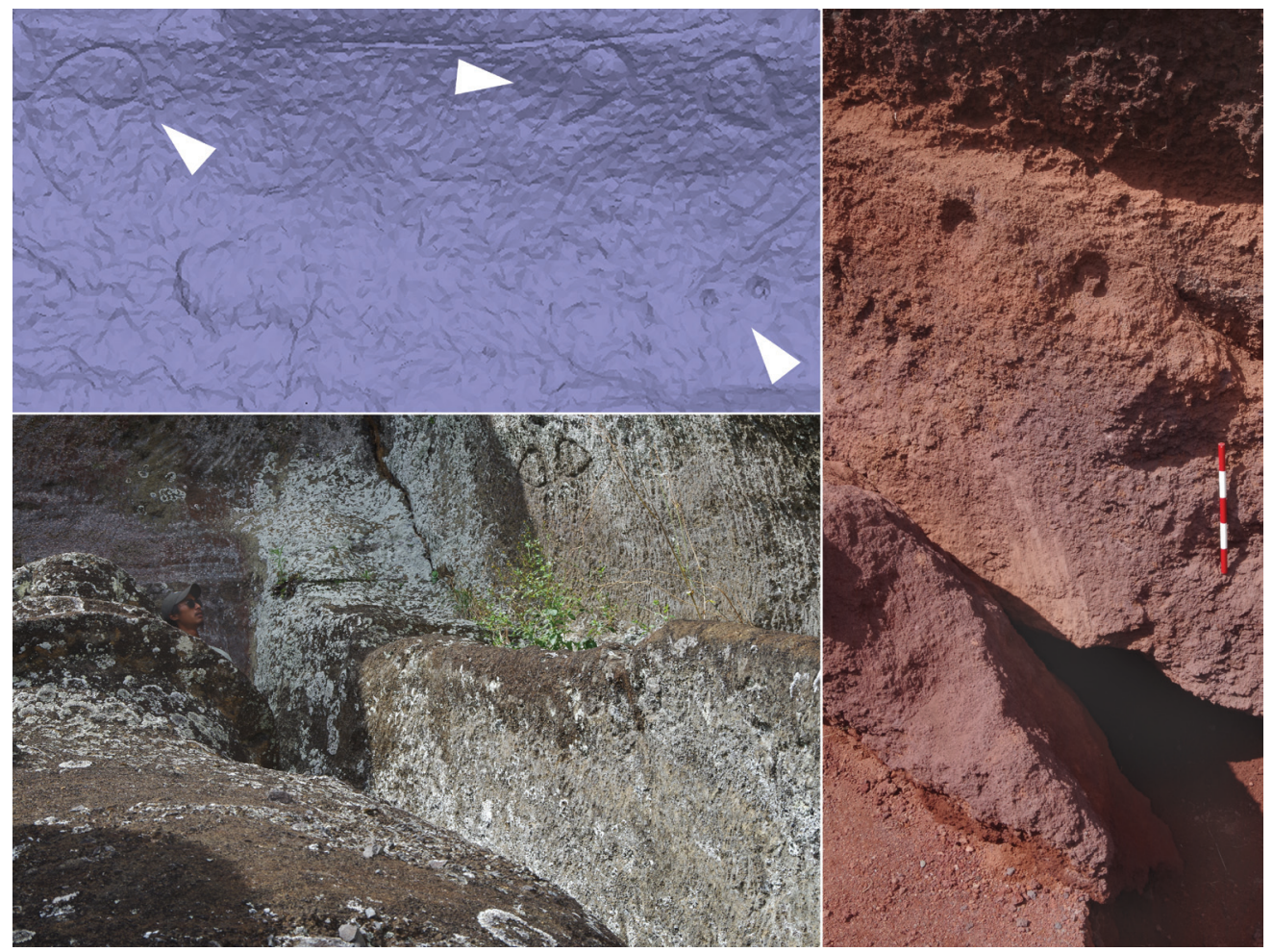

Fig. 5: Carved eyes at the Puna Pau and Rano Raraku quarries. Clockwise from top left: 3Dphotogrammetry image of a single eye and pairs of lenticular and round carved eyes at Rano Raraku (A. Stanford); the pair of carved circular eyes in the interior of the Puna Pau crater; and a pair of carved lenticular eyes on the side of a Rano Raraku quarry bay (photos: M. Seager Thomas).

across the Island and are indicative of islandwide networks of stone use.

LOC's recent work at Puna Pau therefore suggests several themes that we are exploring in other foci of our work on Rapa Nui. These include: the importance of eyes in Rapa Nui belief systems; the idea that quarry locales were potentially special places - to be travelled to, as much as being utilitarian places from which to garner products; and the interconnectivity of stone acquisition, use and meanings attached to Rapa Nui's prehistoric stone architecture and its locations.

\section{The 'eyes' of Rano Raraku}

More than 1,000 moai are known, many of which remain at Rano Raraku, the statue quarry, either still attached to the rock or set up upright within the quarry (Fig. 6). Many others may have been completely buried by subsequent quarrying activities. This suggests that Rano Raraku, with its crater lake, was important not just as a source of freshwater and of stone for moai creation, but also as a place that connected with above-ground and below-ground 'worlds' (Hamilton et al., 2008; Richards et al., 2011).

Rano Raraku has 'eyes' carved in association with its quarry bays and, in 2013, we undertook a review of these to see if they had any similarity in location or style to our Puna Pau 'eyes'. We found one similar pair of circular, protruding eyes carved in a quarry face (Fig. 5), but the c.25 others that we noted were lenticular in shape and similar to the eyes of the Rano Raraku statues when placed on the $a h u$ (Fig. 7). Adam Stanford of Aerialcam has documented these eyes using 


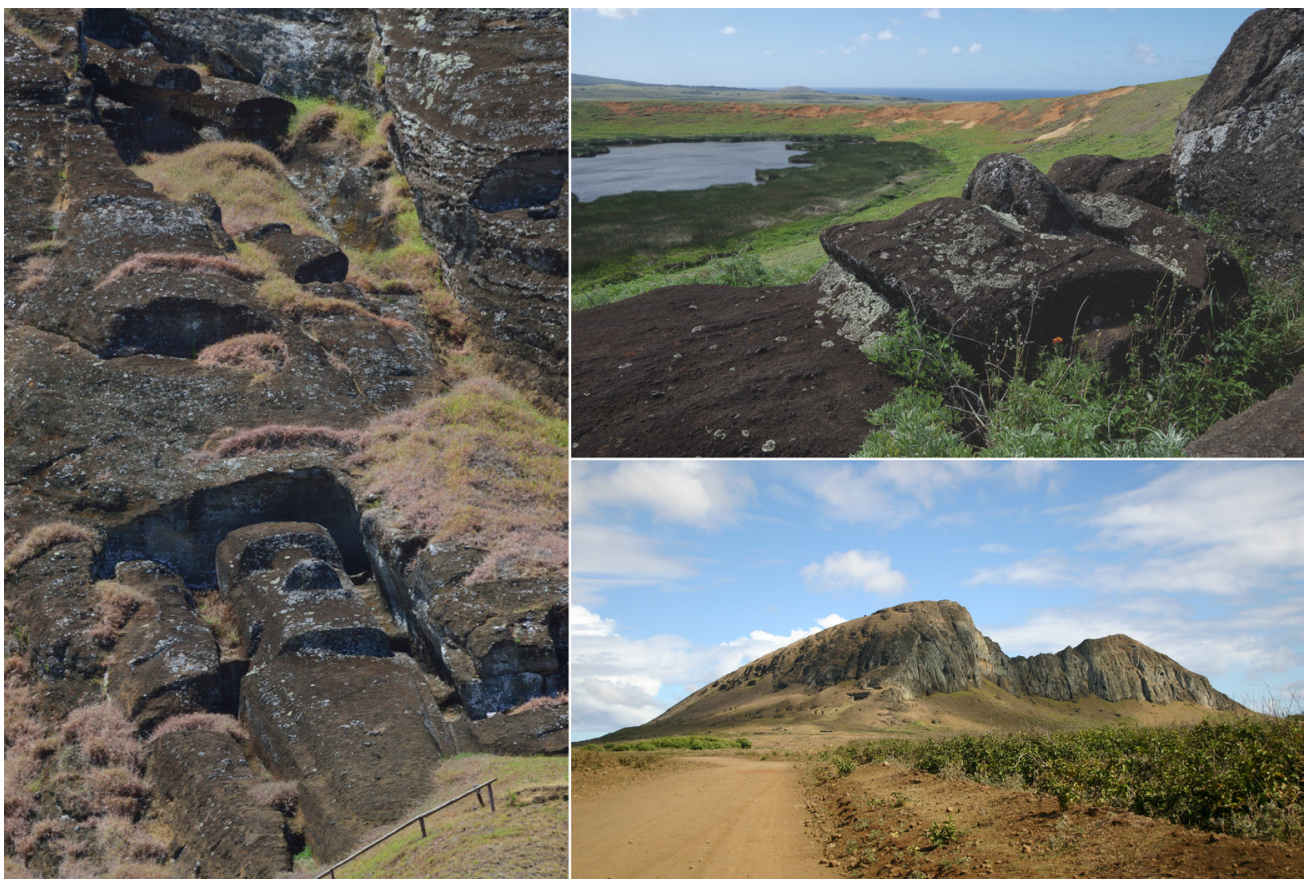

Fig. 6: Rano Raraku statue quarry. Clockwise from left: statues remaining attached to the quarry rock on the crater exterior; the interior of Rano Raraku showing the crater lake and (at the right-hand bottom) the head and upper torso of a large in situ statue; and view of the exterior (photos: M. Seager Thomas).

3D photogrammetry. This provides a record for CONAF and, importantly, has identified eroded carvings of eyes that are no longer readily visible to the naked eye (Fig. 5). Both single examples and pairs of these lenticular eyes occur immediately above or on the sides of many of the Rano Raraku quarry bays, both inside and outside the quarry.

This concern with eyes is interesting. It evokes ideas of the 'living rock' that are noted in Polynesian ethnography: for example, the red scoria of the Marquesas, quarried for stone for ceremonial platforms, was considered to be living and able to replenish itself (Linton, 1925: 165). The watching eyes in the rock faces of the Puna Pau and Rano Raraku craters may point to a conceptual relationship with the eyes of the statues. The Rano Raraku statues are 'blind' while remaining at the quarry - and during transport from the quarry (Fig. 8). It is only those set up on the $a h u$ that have been given eye sockets
(Fig. 7); occasional finds in their vicinity of lenticular coral irises, with scoria or obsidian pupils, suggest that the eyes of these moai were periodically activated by their insertion into the sockets (Martinsson-Wallin, 2007: 46-47). The statues on the $a h u$ were placed looking inland - away from the sea - and thus towards their source where 'seeing' eyes are carved in the quarry faces. This suggests that there was a spatially integrated activation of places and material culture, through the ascription of sentinel attributes, to exert influences on the living.

\section{Follow the statue roads}

Carl Lipo and Terry Hunt have used satellite imagery to map the so-called 'statue roads', with their recumbent roadside 'in-transit' statues, and describe them as emanating like 'spokes from Rano Raraku' (2005:7; Fig. 2). The first recorded sighting was of the southwest statue road by Katherine Routledge 


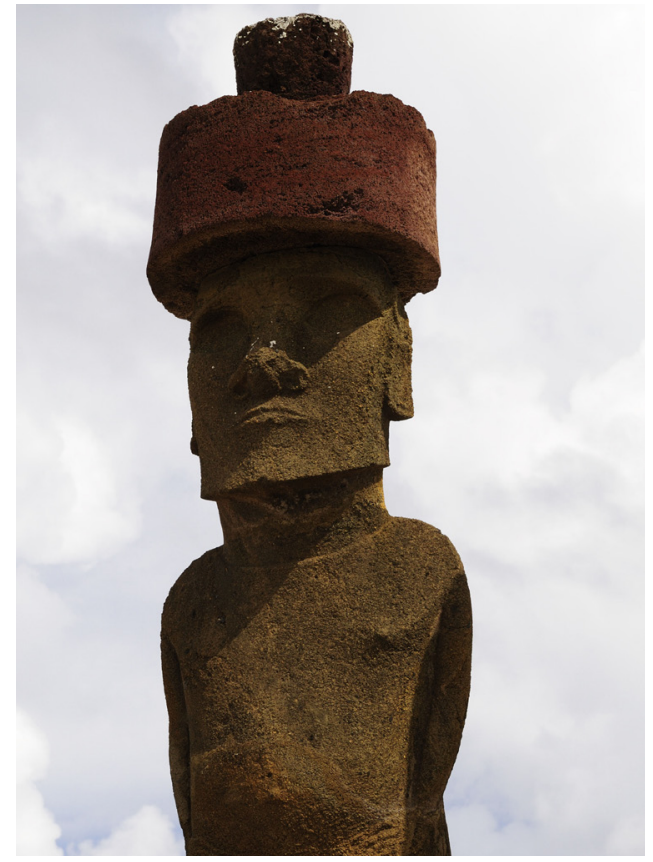

Fig. 7: Detail of a Rano Raraku statue at $A h u$ Nau Nau, showing eye sockets and pukao 'hat' (photo: A. Stanford).

(1919:194), who suggested the likelihood of an arrangement of roads over the Island to account for the many Rano Raraku moai across it. Routledge provided an account of an approach to Rano Raraku with 'at least five magnificent avenues on each of which the pilgrim was greeted at intervals by a stone giant guarding the way to the sacred mountain' (1919:196). This idea was later superseded by the still popular view that the recumbent statues along the roads were abandoned in transit. Lipo and Hunt (2005) suggest that the bifurcating pattern of roads, as they run out from Rano Raraku, reflects the routes that the statues were taken along to different $a h u$. An alternative perspective is that the routes to Routledge's 'sacred mountain' were as important as the transport of some statues away from Rano Raraku. There are indications from past fieldwork that some of the statues were set up along the roadside. One of Routledge's (1919) excavations proximate to the road revealed a pit in which perhaps a moai once stood. Excavations by Thor Heyerdahl and Arne Skjølsvold of two moai along the south-west road (Heyerdahl et al., 1989) suggested the presence of a 'statue platform' behind each of two recumbent moai.

Preliminary geophysical work by LOC in the vicinity of the recumbent moai along the south-west moai road suggests further evidence for stone plinths, congruent with the idea that the statues were originally set up as monuments beside it (Fig. 8). LOC's conservation survey for CONAF, along $2 \mathrm{~km}$ of the same road, systematically considered the weathering patterns of 16 'road-side' moai and the weathering features that might be expected on statues that were originally set upright and had stood for some time before toppling (Hamilton et al., 2013). The weathering patterns on several of these moai suggested that they had indeed been in an upright position for a prolonged period (Fig. 8); this analysis is on-going. This is suggested by such features as having minimal weathering under the chin, a weathered upper belly and a less weathered under belly, and weathering on the under-eye area due to water drip from the overhanging brow. Such weathering patterns would have been unlikely to occur on statues that were in a recumbent position from early on in their history beyond the quarry.

LOC's fieldwork therefore suggests that the roads were monumentalised as much for journeys to Rano Raraku as for the transport of statues from Rano Raraku. Our archaeological survey for CONAF, on an approximate $20 \mathrm{~m}$-wide strip either side of the south-west statue road, produced numerous architectural features of a more domestic nature: chicken houses; canoe-shaped houses; cooking ovens; manavai complexes; and numerous minor quarries for building stone. This denotes that the sacred and everyday worlds were in close physical proximity and that the constant or periodic demarcation between the two was the course of the road itself and its monumentalisation, rather than through an exclusion zone proximate to the road. 


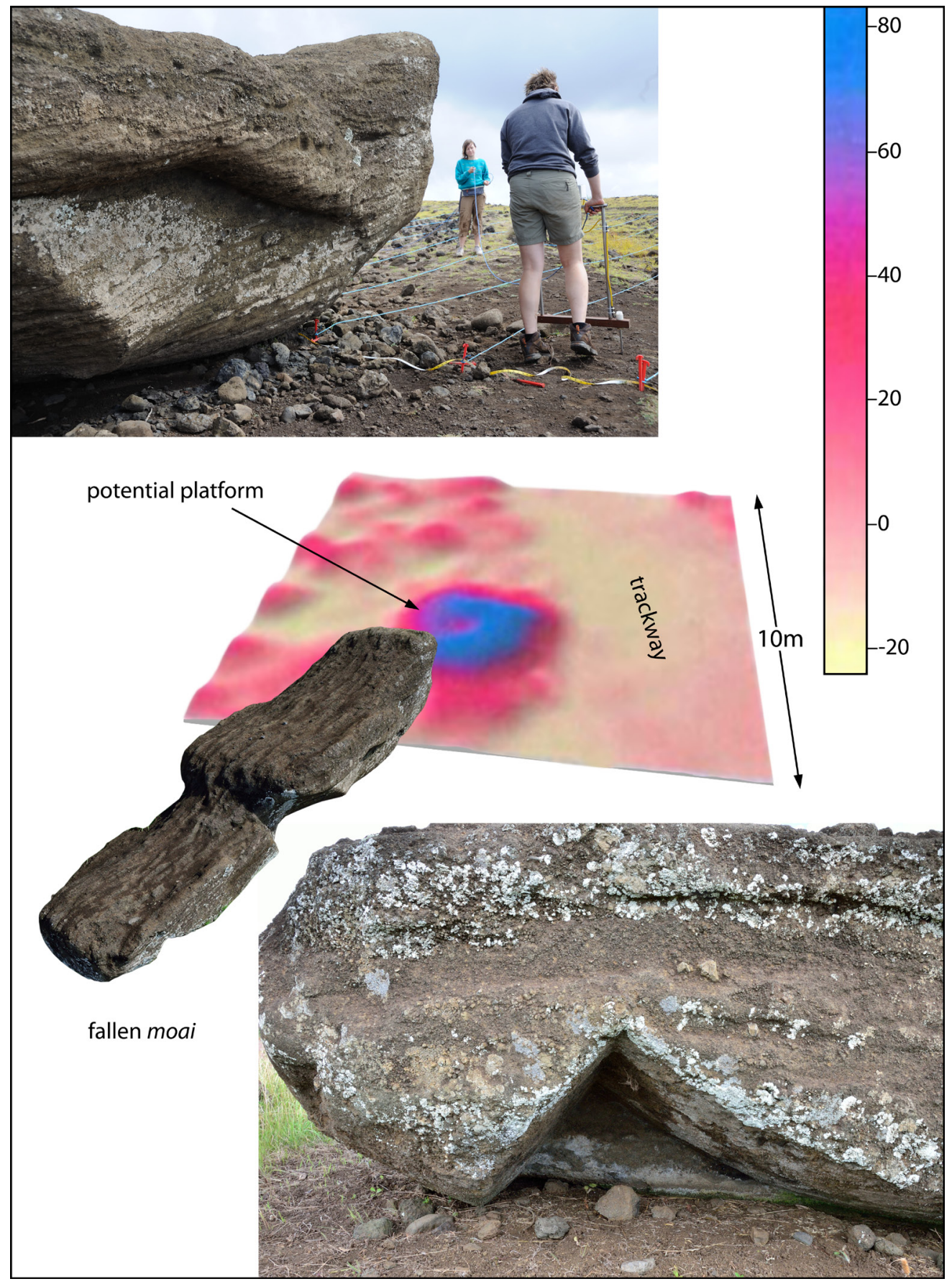

Fig. 8: Geophysical prospection of 'road' statues (top and centre); and (bottom) conservation survey of a 'road' moai showing 'blind' eye with a weathering pattern suggesting that it was once standing (photos: A. Stanford). 


\section{Architectural metaphors at different scales}

Monumentality in stone on Rapa Nui is not restricted to the statues, the statue roads and the $a h u$ on which the statues were set up. Its architecture of the statue-building period suggests a complex intertwining of themes of origin, ancestry and conceptually dangerous boundaries between different worlds that are expressed within the imprints of the smallest to the largest of Rapa Nui's stone structures, and recur spatially from the $a h u$ at the coast to the houses and rock gardens of the interior. LOC's on-going research is exploring the interconnection between these places and their architecture. Here, an example of the repetition of shared themes at different architectural scales and formats is briefly outlined using ahu and hare paenga, and this will be developed in our future work.

The island's coastline is ringed with image $a h u$ and the statues on the $a h u$ are traditionally believed to represent the ancestors. The backs of the ahu platforms face the sea and have crematoria on their seaward side, and the statues on these platforms likewise have their backs to the sea. A few image ahu occur inland, but it is notable that the majority are located at the interface between land and sea. Many of the ahu platforms have canoeshaped bases and all had a poro-paved (beach boulder) ramp at their front (Fig. 1). In front of the $a h u$ were plazas, which are presumed to have been places for ceremonies. Near the $a h u$ these plazas were paved with poro, and beyond, landward, they were cleared of land stone and levelled (Fig. 1). Ahu thus physically link land and sea with two sea metaphors: boat and sea boulders (Hamilton et al., 2011). The positioning of these ahu concurrently monumentalised, blocked and controlled the boundary between land and sea, with sea access being via a poro-paved ramp that is often located to one side of the ahu (Hamilton, 2010). Conceptually, ahu are located at the interface between the world of the living and that of the dead/ancestors, who were processed, deposited and monu- mentalised at the ahu. This land-edge location aligns with the Polynesian concept that on death the soul travels westward across the sea to the point of ancestral origin of the voyaging colonisers (Hamilton, 2010).

We have likewise explored concepts of boundaries and interfaces between conceptual worlds for Rapa Nui's hare paenga (Hamilton and Richards, in press). The hare paenga are often located just beyond and overlooking the ahu plaza, at the juncture with landscapes of the Island's interior that are packed with domestic architecture and rock gardens. The hare paenga share the same visual, searelated metaphors as the ahu in being boatshaped in plan with poro pavements in front. Exceptionally, examples up to c.9m long and $1.6 \mathrm{~m}$ high existed, as reported on during a brief visit by HMS Portland in 1853 (Richards, 2008: 86). In general, however, they have excessively substantial stone foundations with holes drilled at regular intervals to take light, stake superstructures. John Gilbert, Master of the Resolution, described them in 1774 as being covered with combinations of plantain and other leaves with rush and grass thatch, and as being from c.3.5m long and $1.2 \mathrm{~m}$ in height at their centre (Richards, 2008: 17). Interestingly, the hare paenga foundations are made of the stones from many preceding houses, often five or six, and this can be tracked quite precisely via the mismatched combinations of stone widths, half $p u$ (hole/s) and entrance stones reused in the main sections of the house foundations (Fig. 9). Hare paenga can thus be considered to be conceptually and physically ancestral houses with foundations of lineages of stone, just as ahu were places associated with lineages of ancestors.

The hare paenga encountered by Pierre Loti in 1872 (2004: 69-73) are described as darkened/dim inside with - at certain times - sunbeams penetrating the "hole that serves as a door'. The entrance gaps of hare paenga are less than $50 \mathrm{~cm}$ wide and entry required crawling on hands and knees to get through the diminished height of the entry 


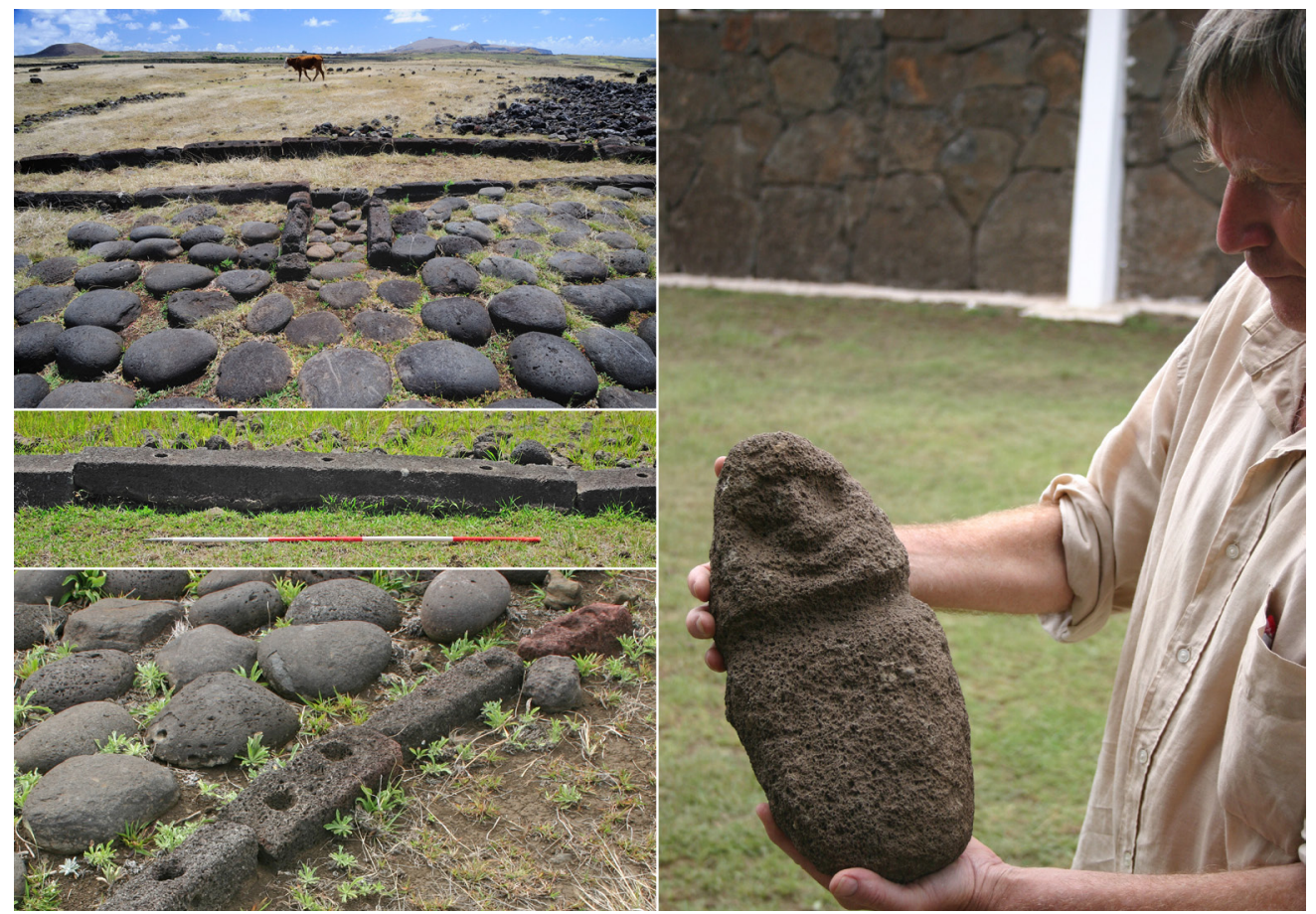

Fig. 9: Hare paenga (canoe-shaped houses). Clockwise from top left: lay-out of the stone base of hare paenga (photo: A. Stanford); Mike Seager Thomas with one of the 'house gods' in the Island's museum (MAPSE) store; and two hare paenga foundations comprising the foundation stones of several former hare paenga (photos: M. Seager Thomas).

point. Several accounts suggest that the hare paenga were used primarily for sleeping (e.g. Loti, 1872 [2004]: 73), but the larger ones may have been community/assembly houses (Metraux, 1971: 200). The excessive bulkiness of the foundation stones suggests that this curbing also had a conceptual role in protecting a key boundary between the exterior worlds of the living and the interior worlds of the sleeping/assembly (Hamilton and Richards, in press). Just as the seaward ramp down the side of an ahu was a conduit between the real and conceptual worlds of land and sea, with the last sight on going down the ramp being the eyes of the statues, entering and exiting a hare paenga appears to have been a graded and controlled transition. For the hare paenga this included a phenomenological transition from light to dark and from upright position to scrabbling on all fours - and vice versa on exit. The hare paenga entrance also appears to have been symbolically guarded. An illustration by Loti (in 1872) shows two small statues either side of a hare paenga entrance and he describes one house entrance as being 'guarded by two granite divinities with sinister expressions' (Loti, 1872 [2004]: 69). Metraux (1940 [1971]: fig. 17) illustrates two small pillars on either side of a house entrance at Ahu Te Peu, which may have served a similar purpose, and mentions the existence of 'small stone images' of a similar size. This has led us to search for small stone statues of which there turn out to be a substantial number in the Island's museum stores (Fig. 9).

Thus, albeit at a different scale to the configuration of an $a h u$, or monumentalisation of the vents and cones and entry/exit routes of fossil volcanoes, the hare paenga may have shared a common, Island-wide cosmology in which the boundaries between different con- 
ceptual works were considered to be dangerous to the extent that they required to be marked and strengthened through architectural devices.

\section{Conclusion}

The above but touches upon some of the themes, findings and interpretative trails of LOC's recent work on Rapa Nui. It is an interim observation with a number of samples waiting dating and further analysis/ fieldwork to come. For the moment what this article hopes to express is an exemplification of the complexity of Rapa Nui's archaeology and its ingenuity of expression that can only be fully revealed when studies have been carried out across multiple categories of architecture and activity. 'Understanding' this ingenuity benefits from its consideration within a Polynesian framework of cosmology. An integrated perspective on Rapa Nui's archaeology and its use of stone par excellence is where the revelation of the weight of its exceptionality must surely lie.

\section{Acknowledgements}

Excavations and fieldwork were undertaken under a Permit issued by the Chilean Ministry of Culture (ORN No 1699 CARTA 720 DEL 31 del 01.2008), and with the support of the Rapa Nui Council of Elders, CONAF and MAPSE.

We would like to thank the Island's Governor, Carmen Cardinali Paoa, and Sonia Haoa Cardinali and Lili Gonzales, for their advice and guidance.

Susanna Nahoe, CONAF's archaeologist, and Francisco Torres H, Director of MAPSE, are Co-Directors of our project and have greatly assisted and advised us in undertaking work on the island. We would also like to thank Enrique Tucki of CONAF for his generous advice and assistance.

The LOC Core Team comprises: Sue Hamilton (Principal Investigator), Colin Richards (CoInvestigator), Kate Welham (Co-Investigator), Jago Cooper (for 2012), Jane Downes, David
Govantes, Mike Seager Thomas, Lawrence Shaw, Adam Stanford and Ruth Whitehouse.

On Rapa Nui we would like to thank the following people who worked with us: Sorababel Fati (Excavation Supervisor) and Rapanui students: Joaquin Soler Hoti, Isaias Hey Gonzalez, Francisa Pakomio Villanueva, Tiki Paoa and Alejandro Tucki Castro.

\section{References}

Diamond, J 2005 Collapse. How Societies Chose to Fall or Succeed. New York: Penguin (Viking Adult).

Flenley, J R and Bahn, P 2003 The Enigmas of Easter Island. New York: Oxford University Press.

Flenley, J R and Bahn, P 2007a Ratted out. American Scientist 95(1): 4-5.

Flenley, J R and Bahn, P 2007b Conflicting view of Easter Island. Rapa Nui Journal 21(1): 11-13.

Hagelberg, E 1995 Genetic affinities of prehistoric Easter Islanders: Reply to Langdon. Rapa Nui Journal 9:16-19.

Hamilton, S 2007 Rapa Nui Landscapes of Construction. Archaeology International 10: 49-53. DOI: http://dx.doi.org/10.5334/ ai.1011.

Hamilton, S 2010 Back to the sea: Rapa Nui's ahu seascapes. in $\mathrm{P}$ Wallin and $\mathrm{H}$ Martinsson-Wallin (eds) Migration, Identity and Culture. Gotland University Press 11, pp. 167-182.

Hamilton, S, Nahoe, S, Richards, $\mathrm{C}$ and Torres, H F 2008 Quarried away. in B David and J Tomas (eds) Handbook of Landscape Archaeology. Walnut Creek CA: Left Coast Press, pp. 176-186.

Hamilton, $\mathbf{S}$ and Richards, $\mathbf{C}$ In press Between realms: entering the darkness of the hare paenga in ancient Rapa Nui (Easter Island). in M Dowd and R Hensey (eds) The Archaeology of Darkness.

Hamilton, S, Seager Thomas, $\mathbf{M}$ and Whitehouse, R 2011 Say it with stone: constructing with stones on Easter Island. World Archaeology 43(2): 167-190. DOI: 
http://dx.doi.org/10.1080/00438243.20 11.586273.

Hamilton, S, Seager Thomas, M, Stanford, A, Shaw, L, Welham, K and Whitehouse, R 2013 LOC Preliminary Multiscalar Survey of the South-west Section of the Ara Moai: including an assessment of conservation priorities and proposals for the establishment of a trekking route. Conducted for and report submitted to CONAF, Rapa Nui, February, 2013.

Heyerdahl, T, Skjølsvold, A and Pavel, P 1989 The 'walking' moai of Easter Island. Oslo: Occasional Papers 1, The Kon Tiki Museum, pp. 36-64.

Hunt, T L and Lipo, C P 2006 Late colonization of Easter Island. Science 311: 16031606. DOI: http://dx.doi.org/10.1126/ science.1121879.

Hunt, T and Lipo, C 2007 Rethinking Easter Island's ecological catastrophe. Journal of Archaeological Science 34/3: 485-502.

Linton, R 1925 Archaeology of the Marquesas Islands. Honolulu, Hawi,i: Bernice P. Bishop Museum Bulletin 23.

Lipo, C and Hunt, T 2005 Mapping prehistoric statue roads on Easter Island. Antiquity 79 (303): 158-168.

Loti, P (Julien Viaud) 1872 [2004] Diary of a cadet on the warship La Flore. in A M Altman (trans.) Easter Island 1864-1877, The Reports of Eugene Eyraud, Hippolyte Roussel, Pierre Loti, and Alphonse Pinart. Los Osos: Easter Island Foundation, pp. 63-103.
Martinsson-Wallin, H 1994 Ahu: The Ceremonial Stone Structures of Easter Island. Uppsala: Societas Archaeologica Upsaliensis.

Martinsson-Wallin, H 2007 Aku Aku from Afar. Rapa Nui: Rapa Nui Press Museum Store.

Metraux, A 1940 [1971] Ethnology of Easter Island. Honolulu, Hawaii: Bernice P. Bishop Museum Bulletin 1960 [reprint].

Richards, C, Croucher, K, Paoa, T, Parish, T, Tucki, E and Welham, K 2011 Road my body goes: recreating ancestors from stone at the great moai quarry of Rano Raraku, Rapa Nui (Easter Island). World Archaeology 43(2): 191-210. DOI: http://dx.doi.org /10.1080/00438243.2011.579483.

Richards, R 2008 Easter Island 1793 to 1861: Observations by Early Visitors before the Slave Raids. Los Osos, LA: Easter Island Foundation.

Routledge, K 1919 [Facsimile 2005] The Mystery of Easter Island. Rapa Nui: Rapa Nui Press.

Sahlins, M 1955 Esoteric efflorescence in Easter Island. American Anthropologist, New Series 57(5): 1045-1052.

Williamson, R W 1933 Religious and Cosmic Beliefs of Central Polynesia. Cambridge: Cambridge University Press.

Wilmhurst, J M, Hunt, T L, Lipo, C P and Anderson, A J 2010 High-precision radiocarbon dating shows rapid and recent initial colonization of eastern Polynesia. Proceedings of the National Academy of Science 108(5): 1815-1820. DOI: http:// dx.doi.org/10.1073/pnas.1100447108.

How to cite this article: Hamilton, S 2013 Rapa Nui (Easter Island)'s Stone Worlds. Archaeology International, No. 16 (2012-2013): 96-109, DOl: http://dx.doi.org/10.5334/ai.1613

Published: 24 October 2013

Copyright: (c) 2013 The Author(s). This is an open-access article distributed under the terms of the Creative Commons Attribution 3.0 Unported License (CC-BY 3.0), which permits unrestricted use, distribution, and reproduction in any medium, provided the original author and source are credited. See http://creativecommons.org/licenses/by/3.0/. 